\title{
Marketing Orientation Of Educational Institutions In The Field Of Project Management
}

Zlatko Barilović

Baltazar Adam Krčelić College

of Business and Management,

Zaprešić, Croatia

zlatko.barilovic@vspu.hr

DOI 10.5592/otmcj.2014.1.4

Research paper

\author{
Mirna Leko Šimić \\ Faculty of Economics, \\ Osijek, Croatia \\ lekom@efos.hr
}

\author{
Helena Štimac \\ Faculty of Economics, \\ Osijek, Croatia \\ shelena@efos.hr
}

\section{Keywords}

Project management, Marketing orientation, Marketing in education, Specialist graduate Professional study project Management, Construction
IN THE CONDITIONS OF MODERN BUSINESS, ALL BUSINESS SYSTEMS, THEREFORE ALSO IN THE FIELD OF CONSTRUCTION,NEED TO FIND NEW SOLUTIONS ON A DAILY BASIS IN ORDER TO MAINTAIN AND INCREASE THEIR COMPETITIVENESS ON THE MARKET. IT IS POSSIBLE TO ACHIEVE COMPETITIVENESS PRIMARILY BY PERFORMING NONSTANDARD PROCEDURES, SUCH AS PROJECTS. Having in mind that the number of projects is constantly rising in the world, it is necessary to achieve the highest possible level of successful and efficiently carried out projects. In order to achieve this it is necessary to develop certain elements of project competence in people who participate in planning, preparing and conducting projects. Developing these competences is possible by combining knowledge and experience, primarily through a lifelong learning process. Since the number of organizations that carry out certain forms of formal or informal education in the field of project management is rising in the Republic of Croatia, each of these institutions needs to build their competitiveness on the implementation of a marketing business concept. Because of the aforementioned reasons the authors analyse the supply of educational services in the field of project management in the Republic of Croatia, with a special overview of the specialist graduate professional study of Project Management conducted at the "B. A. Krčelic" College of Business and Management in Zaprešić. This paper places an emphasis on projects based on the marketing orientation of the study, by means of which the College increases the quality of its educational services and tries to achieve a competitive advantage on the educational market. 


\section{INTRODUCTION}

In modern business conditions, all organizations need to take into account the need to keep and increase their competitiveness, which is the basis for success or lack of it in any organization (Porter, 2009). Organizations that want to outdo their competitors in their field of activity need to take into account the following measures on a daily basis (Hauc, 2007:12): quality, minimal costs, minimal duration and maximum or sufficient production. Managing change is of special importance for the competitiveness of any organization. If we want to manage change successfully, we need to perform non-standard activities or processes on a daily basis (that is, something that is not done often or continually), and these processes are called projects (Hauc, 2007; Vrečko and Barilović, 2009).

It can be said that the business success of any business system on the current modern market (therefore also in the field of construction) needs to be based precisely on efficiently and successfully realized projects. The number of projects is constantly rising in the world, and the consequence of that is the increasingly complex project business, which is why we can talk about the multi-project environment of today's business systems (Hauc, Vrečko, Barilović, 2011; IPMA ICB, 2006). Managing the multi-project environment becomes ever more important and numerous questions arise, among which an especially important one is: will all the social environments be able to understand the importance of efficient and successful realization of projects.

If we want to achieve the largest possible level of successfulness and efficiency of projects in any field of activity, it is vitally important to develop certain competence elements in people who participate in planning, preparing and conducting projects. Developing such competences is possible by combining knowledge and experience, primarily through the lifelong learning process (Eurydice, 2002).

According to the findings of some research (Vrečko and Barilović, 2009; Radujković, Barilović, Nahod, 2011; Barilović, 2012) the competences needed for successfully managing projects can in the Republic of Croatia be gained at several institutions that carry out certain forms of formal or informal education in the field of project management. Since the number of institutions dealing with developing project competences is constantly rising, each of them will have to build their competitiveness on the implementation of marketing business concept as well.

\section{Applying A Marketing Concept In The Field Of Education}

Marketing orientation is orientation to people in the market (consumers, users, buyers), collectively called clients. In the marketing concept, an active relation of the supplier to the consumer is ensured as well as a business concept based on consumer satisfaction. Discovering the needs of the clients, and differentiating from competitors on the market becomes the driving force of success of any organization (Kotler and Keller, 2008; Vranešević, Vignali, Vrontis, 2004; Grbac, 2012). Marketing in education can be viewed in the context of nonprofit marketing and service marketing.

Non-profit organizations marketing can be defined as activities aimed at designing and enhancing planning, executing, distributing and communicating the activities of organizations that contribute to a certain public but their main purpose is not generating profit (Pavičić, 2003:31).

As has been mentioned earlier, marketing in education can also be viewed in the context of services marketing. Services can be viewed as activities or benefits that one party can offer to the other, mostly intangible, and which do not result in ownership. Producing them can be, but does not have to be, connected with a tangible, physical product (OzretićDošen, 2002:19 according to Kotler and Armstrong, 1991). A service-providing company has to decide whom they want to provide the service to, discover the wishes of the service user and define a strategy that will exclusively be dedicated to providing the service in question (OzretićDošen, 2002:33 according to Carlzon, 1987). A service, just like a product, must have use value because in the contrary producing it would make no sense (Grbac and Meler, 2007:8).

Taking into account the previously mentioned specificities of non-profit marketing and service marketing, it is clear that educational institutions will have to build their marketing strategies having these specificities in mind.

\section{The Supply Market Of}

\section{Educational Services In The} Field Of Project Management In The Republic Of Croatia

Project management can be viewed as that part of general management of an organization that is in charge of conducting the entry project strategy or other project orders, for preparing project start-up, managing its realization until the close-out. At the same time, it is in charge of achieving the planned indirect, direct or other economic effects, depending on the project, that will be secured by the project results, i.e. the use (Hauc, 2007:180).

Since project management belongs to the interdisciplinary field of science (NVZ, 2009:31), and projects are in practice used for growth and development of all business systems, the potential users of educational services in the area of project management are all the individuals participating, in any role, in any of the project phases and all the organizations carrying out projects. According to the findings of a research (Uhlir, 2011) business systems in Croatia comprehend the importance of the need for developing project competences of their employees. 
Research conducted by the Anderson Economic Group (AEG) as ordered by the Project Management Institute (PMI) showed that in 2006 over 2.4 million employees in 11 of the world's leading economies participated in projects. It is expected that by 2016 this number will reach over 32.6 million employees in the same states (ISO, 2012).

The level of project competence of individuals in Croatia is currently much lower in comparison to to more developed EU countries (IPMA, 2012) what makes it evident that developing educational services in the field of project management has a reasonably good perspective on the educational market in the Republic of Croatia.The tradition of education in the field of project management in the Republic of Croatia is very long, and the Faculty of Civil Engineering at the University of Zagrebcan be singled out. The first courses related to project management were introduced there in the 1970 s (Mlinarićandlzetbegović, 2010). Nowadays, its Construction Management Departmenthas a mojor role in developing project competences. Knowledge in the field of project management in the Republic of Croatia is currentlyattainable through courses at various higher education institutions (faculties, universities of applied sciences and colleges), however the number of organizations which offer integral education programmes in the field of project management (especially formal education programmes) is still to small compared to more developed countries.

The following have been recognized as some of the most important organizations that are currently offering various programmes of formal and informal education and certification programmes in the Republic of Croatia, (Barilović, 2012:33):

> "Baltazar Adam Krčelić" Accredited College of Business and Management, Zaprešić- Specialist graduate professional study of Project Management
Croatian Association for Project Management (CAPM) - education programme in the field of project management and IPMA certification

- Project Management Institute (PMI) PMI branch Zagreb, Croatia - education programme in the field of project management and PMI certification

- Faculty of Civil Engineering at the University of Zagreb - conducts education programmes in the field of project management at the graduate, postgraduate specialist and postgraduate doctoral studies

- Faculty of Economics of the University of Split - specialist graduate professional study of Management, which offers a major in Project Management

- Faculty of Economics of the University in Osijek - professional usavršavanjaprogramme Managing the project cycle

- Algebra Academy - Project Management Academy's programme

$\checkmark$ Wirtschaftsförderungsinstitut (WIFI) - specialization programme Project Manager(Specialist in project management)

- Institute for management - education programme Project leader for EU funds

- Business Academy Experta - specialization programe EU funds project manager and Project manager

As has already been stated, the number of organizations in Croatia that deal with developing project competences is constantly rising (what is understandable having in mind the lack of educated project managers) this is precisely why each of these organizations will have to build the competitiveness of their educational service on the implementation of a marketing business concept. In the continuation we shall briefly show the implementation of marketing orientation on the example of the study of Project management at the "B. A. Krčelić“" Accredited College of Business and Management, Zaprešić.
A Research Into The Marketing Orientation On The Project Management Study At The "Baltazar Adam Krčelič" College Of Business And Management

The "B. A. Krčelič“ Accredited College of Business and Management, Zaprešić conducts a specialist graduate professional study of Project Management. The main partner in conducting this study is the Ruđer Bošković Institute (IRB), with which the College signed an Agreement on long-term cooperation on designing, conducting and developing the study of Project Management in 2004. Beside the two partner institutions, a number of foreign project management experts participate in the teaching process.

The marketing programme of the study Project Management at this College can be observed in the context of a classical marketing programme comprised of the elements of product/service, price, distribution and promotion.

The product/service of the study is comprised of the following aspects: syllabi and the curriculum, additional services, the number of active students and graduates, and the infrastructure for enhancing the transfer of knowledge to students.

It is possible to observe the price element from the economic and the psychological standpoint. Economically, the price determines the income and the profit of the service-providing organization. Psychologically, the price of the service is the element that affects the determination of value the service has for the user, it is an indicator of quality and has an important role in creating and maintaining the image (OzretićDošen, 2002). Educational services according to LekoŠimić and Čarapić (2008) have both explicit costs (capital and labour costs) and implicit costs (costs of accommodation, food, transport for those who are getting their education outside of their place 
VŠPU (study of Project Management)

\begin{tabular}{|c|c|c|c|}
\hline DESCRIPTION & & $\mathbf{N}$ & $\%$ \\
\hline \multirow{2}{*}{ Year of study } & 1st year & 138 & 68 \\
\hline & 2nd year & 64 & 32 \\
\hline \multirow{2}{*}{ Student status } & Full-time students & 81 & 40 \\
\hline & Part-time students & 121 & 60 \\
\hline \multirow{2}{*}{ Gender } & Male & 83 & 41 \\
\hline & Female & 119 & 59 \\
\hline \multirow{6}{*}{ Age } & $21-25$ & 98 & 49 \\
\hline & $26-30$ & 52 & 26 \\
\hline & $31-35$ & 26 & 13 \\
\hline & $36-40$ & 8 & 4 \\
\hline & $41-45$ & 10 & 5 \\
\hline & over 46 & 8 & 3 \\
\hline \multirow{4}{*}{ Attendance } & over $75 \%$ & 151 & 75 \\
\hline & $50-75 \%$ & 41 & 20 \\
\hline & $25-50 \%$ & 8 & 4 \\
\hline & under $25 \%$ & 2 & 1 \\
\hline
\end{tabular}

\section{Table 1. Sample description}

of residence, literature etc.). The price of the study, since this is a private institution, has been defined taking into account the previously mentioned economic costs and positive business results.

Distribution tells us which way the product/service reaches the end user, i.e. which ways it uses thereby. Distribution does not include movement of goods as much as it does the transfer of ideas and providing services, what results in very short marketing channels (Meler, 2003). Distribution in education does not only signify the receivers of the educational service but also where and how, i.e. in what way (Štimac, 2012). The distribution mix of the study of Project Management is comprised of the location of the study, teaching organization and a distance-learning system.

Promotion in education is most frequently a communication process between the institution and the existing or potential students, with the aim of creating a positive attitude towards the products and services. Promotion is efficient if other elements of the marketing mix play their roles well, i.e. promotion cannot compensate for the weaknesses in the efficiency of other elements. The institution needs to start communication with clearly defined communication tasks, in order to build a positive image of the institution, to attract potential stakeholders (students, sponsors, partners), and establish loyalty (Štimac, 2012:157). Promotion of the study of Project Management is carried out by means of promotional materials, the Student Council and the Alumni club, and by being present in the media. Also, the study is being promoted by means of its web-site, organization of various events, student and teacher participation in various conferences etc. The study is also promoted through the publishing activities of the College and cooperation with partner institutions such as the Croatian Association for Project Management (CAPM) and the International Project Management Association (IPMA).

In order to research the marketing orientation of the study of Project Management, a questionnaire was drawn up containing statements regarding the projects and activities the College had initiated with the aim of increasing competitiveness of its studies. Measuring the marketing orientation was observed through 11 variables derived from the following six main categories of marketing orientation:

1. Cooperation between the College and the Ruđer Bošković Institute (IRB)

2. Cooperation between the College and the Croatian Association for Project Management (CAPM) and the International Project Management 
The fact that the study is organized in cooperation with the Ruđer Bošković Institute (IRB) additionally contributes to the image of the study
$4 \cdot 30$
0.88

Cooperation of the College with the Croatian Association for Project Management (CAPM) and the International Project Management Association (IPMA) contributes to the image of the study

The possibility of getting the IPMA international certificate for project management can give PM students an additional competitive advantage

Harmonization of the PM study programme with the world PM standards proscribed by the IPMA through the IPMA REG system contributes to the quality of the study

IPMA REG logo on the diploma supplement adds value to the PM study diploma

The possibility for PM students to participate in Young Crew Croatia (YCC) can contribute to the development of project competences and acquiring first practical project experience

Conducting project-based classes (e.g. preparing start-up documents for actual projects) at the PM study contributes to the development of students' project competences

Organizing international conferences and project info-days at the College improves the image of the institution, and especially the image of the study of PM.

Including foreign teachers in the teaching process increases the quality of the study.

Including teachers from the IRB in the teaching process increases the quality of the study.

The possibility for PM students to continue their studies at the postgraduate studies organized by the Faculty of Economics in Osijek improves the image of the College.

Average grade

$4 \cdot 34$

\section{Table 2. Student attitudes regarding certain aspects of marketing orientation of the study}

\section{Association (IPMA)}

3. Raising the level of students' project competence by conducting projectbased classes

4. Organising international and domestic scientific and professional conferences

5. Including foreign teachers in the teaching process at the study of Project Management

6. Cooperation of the College and the Faculty of Economics in Osijek with the aim of enabling students to continue their education at postgraduate specialist and doctoral studies

The research was conducted among the first and the second year students of Project Management, on a sample of 202 students, what accounts for $51.13 \%$ of active students. The research was carried out in April 2012. Table 1. shows the main characteristics of the sample description.
The findings of this research have shown very good results in all the observed categories (the total average grade of all the observed elements is 4.34). The students ranged all the given statements with grades over 4 on average (according to a Likert scale ranging from 1 to 5), what means that they mostly or completely agree with them.

Out of the above-mentioned 6 main categories, the best average grade (4.43) was achieved by elements 
connected with the cooperation of the College with CAPM and IPMA, what points to great importance of connecting educational programmes with relevant domestic and foreign organizations from the field. What follows in importance attributed by the students is organizing scientific and professional conferences as a possibility of improving the image of the educational programme (4.34), then the possibility of further development upon completing the educational programme (4.31). In this case, it is the possibility to continue their studies at the postgraduate level in cooperation with the Faculty of Economics in Osijek. Somewhat lower average grades (although still very high) were given to the participation of foreign teachers in the teaching process (4.26), elements of cooperation with scientific institutions such as IRB and using specific teaching methods (4.22).

In the further analysis of the results of the research the students' average grades were observed regarding their status (full-time and part-time) and the year of study (first and second year of graduate study).

The average grades of part-time students are generally higher than those of full-time students in all 6 observed categories ( 4.36 versus 4.20 ), while the best grades were given to the cooperation of the College with CAPM and IPMA (4.43), the possibility of further development at the postgraduate level (4.42) and organizing scientific and professional conferences. Full-time students value the cooperation with CAPM and IPMA most, with the average grade of 4.42 , followed by organizing conferences (4.26) and the importance of including foreign teachers in the teaching process (4.22).

According to the year of study, first year students give better average grades to all the observed categories except including foreign teachers in the teaching process. The average grade for all the categories for first year students amounts to 4.33 , while for second year students it is 4.22. First year students give the best grades to cooperation with CAPM and IPMA (4.50), organizing conferences (4.38) and the possibility of continuing their studies (4.38). Second year students give the highest average grade to including foreign teachers in the teaching process (4.30), followed by the cooperation with CAPM and IPMA (4.28), and then to organizing conferences (4.23).

Such findings go in favour of the idea that it is possible to raise the level of competitiveness of and educational service in the field of project management by means of marketing orientation, and especially because all the previously listed elements were given very high grades, regardless of the observed group.

\section{Conclusions}

The challenges all business systems are faced with in today's business world are the rapid and constant changes, competitiveness, globalization, global strategic crises etc. In order to maintain or increase their competitiveness in such conditions of modern business, all business systems need to try to coordinate several elements, namely primarily quality, costs, time and the maximum or sufficient production. It is no longer possible to respond to these challenges only by continuous business, but a solution has to be found in non-standard, target-oriented, time-limited, unique and innovative processes, i.e. projects. It can be said that precisely the efficiently and successfully conducted projects should be the foundation of competitiveness of any organization, regardless whether it belongs to the profit or non-profit sector.

This is why it is extremely important that people who participate in any project phase, and especially project managers, have the competences necessary for managing projects successfully. In Republic of Croatia, such competences can be gained through various forms of formal and informal education. Since the field of project management has become increasingly popular over the past years (especially because of Croatia's joining the European Union), there has been a rapid increase of organizations that offer educational services in the field of project management on the Croatian market. Such services are currently offered in the form of various courses, seminars, workshops and studies. Since the number of such organization is rising, it is clear that any institution of education will have to build its competitiveness on the marketing business concept. This fact has been confirmed by the findings of the research carried out at the study of project management conducted by the “B. A. Krčelić” College of Business and Management Zaprešić.

\section{References}

Barilović, Z. (2012), Marketinška orijentacija i kvaliteta obrazovne usluge s područja projektnog menadžmenta, Poslijediplomski specijalistički završni rad, Ekonomski fakultet u Osijeku

Eurydice (2002), Key competences: A developing concept in general compulsory education, Eurydice, Brussels

Grbac, B. (2012), Stvaranje i razmjena vrijednosti, Ekonomski fakultet Sveučilišta u Rijeci, Rijeka

Grbac, B. and Meler, M. (2007), Realizacija poslovne ideje - od ideje do proizvoda/ usluge, Ministarstvo gospodarstva, rada i poduzetništva, Zagreb

Hauc, A. (2007), Projektni menadžment i projektno poslovanje, M.E.P. Consult, Zagreb

Hauc, A., Vrečko, I. and Barilović, Z.. (2011),,,A Holistic Project-knowledge Society as a Condition for Solving Global Strategic Crises“,Društvena istraživanja, Vol.20/2011 No. 4 (114), pp. 1039-1060

International Organization for Standardization (ISO), available at: http://www.iso.org/iso/ home/news_index/news_archive/news. htm?refid=Ref1662 (accessed 02 November 2012)

International Project Management Association (2006),ICB - IPMA Competence Baseline 
Version 3.0, International Project Management Association, IPMA, Nijkerk

International Project Management Association (2012),IPMA Certification Yearbook 2012., IPMA

Kotler, P. and Keller, K.L. (2008),Upravljanje marketingom, 12.izdanje, Mate, Zagreb

Leko Šimić, M. and Čarapić, H. (2008) „Znanje marketinga u funkciji marketinga znanja“, in Grbac, B. i Meler, M. (Ed.), Marketing u društvu znanja, Ekonomski fakultet Sveučilišta u Rijeci i CROMAR, Rijeka, pp. 87-98

Meler, M. (2003), Neprofitni marketing, Ekonomski fakultet u Osijeku, Osijek

Mlinarić, V. and Izetbegović, J. (2010), „The department of construction management: A historical overview“, Organization, Tehnology \& Management in Construction: An International Journal, Vol.2 No.1., pp. 99-102.

Nacionalno vijeće za znanost (2009), Pravilnik o znanstvenim i umjetničkim područjima, poljima i granama. NN (br.118 od 3o.rujna 2009)

Ozretić Došen, Đ. (2002),Osnove marketinga usluga, Mikrorad, Zagreb

Pavičić, J. (2003), Strategija marketinga neprofitnih organizacija, Masmedia, Zagreb

Porter, M.E. (2009),Konkurentska prednost, Masmedia, Zagreb
Radujković, M., Barilović, Z. and Nahod, M.-M. (2011),, Povećanje međunarodne prepoznatljivosti organizacija koje izvode obrazovanje s područja upravljanja projektima implementacijom IPMA REG sustava“ in Barilović, Zlatko et al (Ed.) Zbornik radova znanstveno-stručnog skupa s međunarodnim sudjelovanjem „Projekti i projektni menadžment“, Zagreb, 25.-26 February 2011.Visoka škola za poslovanje i upravljanje, s pravom javnosti, „B.A.Krčelić“, Zaprešić, pp. 793-801.

Štimac, H. (2012), Marketing i kvaliteta usluge u kontekstu internacionalizacije visokoškolskog obrazovanja, Doktorska disertacija, Ekonomski fakultet u Osijeku

Uhlir, ž. (2011), Utjecaj procesa certificiranja projektnih menadžera na razvitak projektnog menadžmenta u Republici Hrvatskoj, Magistarski rad, Ekonomski fakultet Zagreb

Vranešević, T., Vignali, C. and Vrontis, D. (2004),Upravljanje strateškim marketingom, Accent, Zagreb

Vrečko, I. and Barilović, Z. (2009),Osposobljenost projektnih menadžera u Republici Hrvatskoj i Republici Sloveniji, in Skledar, Nikola (Ed.),Zbornik radova. VŠPU, Zaprešić, pp. 403-429 